\title{
QUALITY ASSURANCE-STUDENT INVOLVEMENT CONFLUENCE: EXPLORING GAPS AND IMPLICATIONS FOR HIGHER EDUCATION INSTITUTIONS IN ZIMBABWE
}

\author{
M. Ncube \\ Journalism and Media Studies (Alumni) \\ National University of Science and Technology \\ Bulawayo, Zimbabwe \\ e-mail: sabebhebhencube@gmail.com / https://orcid.org/0000-0001-6683-7688
}

\section{ABSTRACT}

Since postulation, the student involvement $(\mathrm{SI})$ theory of development by Alexander Astin has been crucial in reconfiguring and maximizing the higher education experience through improving the quality. Student-input is instrumental in examining student-experience and managing the quality in higher-education-institutions (HEls). Amidst industrial revolutionary technologies that transcend bureaucratic procedures governing HEls, involving students, most of whom are technologically savvy, potentially sparks innovation. Transitioning from education 3.0 to doctrine education 5.0 has implications of quality assurance (QA)-student involvement (SI) confluence on Zimbabwe's HEls. Two out of nine HEls in Matabeleland were selected for convenience of location. Findings show SI should precede QA outcomes although HEI practices do-not reflect this important means-to-an-end-relationship. To attain quality under the doctrine, SI must satisfy students on all doctrine 5.0's standards. Few HEl-programmes target SI for QA. Programming gaps affect student-learning, hence innovative learning-systems must respond to evolving societal-needs and satisfy students-diversity including in curriculum-development; staff-quality; and research and development-projects. Thus, SI reflects placation at best and tokenism at worst. Government/HEls must export leading academics, fund their attainment of updated skills-set from modernised countries, and deploy them to reorient HEI programmes while concurrently modernising industries to ensure newly attained skills have platforms for applicability.

Keywords: student-involvement, quality-assurance, confluence, HEls, criteria

\section{INTRODUCTION}

From the time of inheriting the colonial system of education, Zimbabwean Higher Education Institutions (HEIs) has not done much to align with contemporary changes and industrial demands (Tapera 2016). Instead of professors partnering students in coming up with new ideas set to improve the state of university curricula, they continued with an archaic system (Garwe 2014). About 39 years after independence, the government of Zimbabwe is just beginning to see reason in implementing changes set to refocus university education, joining the rest of the 
world in making quality assurance (QA) and promotion the thrust of its institutions. As denoted by Aikman (2017), academia should join all societal decision makers in formulating ideas and thus projects targeted at improving and aligning the state of the world.

With diminishing industry in Zimbabwe, graduates have been exported en-mass into countries that have moved from archaic systems to new technologies that continue to evolve. In these new environments, graduates are subjected to technological familiarisation retraining or risk being unemployable (Tapera 2016; Garwe 2014). Not only have the revolutions called into question the meaning of humanity, but that of education systems as well. Relevance is thus fast becoming an issue in the continuum of technological evolution, hence the need for more ideas from the academic fraternity. Doctrine Education 5.0 coined by the Ministry of Higher and Tertiary Education, Innovation, Science and Technology Development redefines all fields of higher education (HE) in the country with HEIs accountable for QA and success.

This research explored occurrences at the QA and student involvement confluence in terms of activities, gaps and implications. It also sought to establish the extent to which students want to be partnered in attaining quality that guarantees relevant and critical graduates. The enrolment of technologically savvy students with latest industrial and social experience has ushered some unique skills into the HEIs learning environment. Students are not only gaining knowledge from HEIs but are also competently in possession of most of the skills HEIs seek to impart to them (Astin 1999). Conversely, the need to catch up with global demands piles pressure on HEIs to fulfil the expanded education 5.0 mandates. The urgency to catch up demands revolutionary and relevant ideas. Recognising the diversity of knowledge input students bring to the learning environment, student involvement presents a perfect opportunity for a conflation of ideas for QA. The extent of student involvement in HEIs governance platforms like Council, Senate among other platforms they sit in is not clear necessitating a study to determine students' roles QA processes and identify student involvement policy gaps.

\section{STATEMENT OF THE PROBLEM}

The higher education sector has not been spared in the hype of evolvement and technological revolutions that are changing world economies and paving way for new technologies. Instead of HEIs being in sync with technologies that emerge from the industry, the reactionary response of some universities is adversely affecting curricula and negating acquired skills even before leaving institutions. University educators are still focused on a compliance centred, uninvolving education system that shuts out students' ideas making the system somewhat top down and thus authoritarian. This is what scholars underscore as discretion exercised by "front-line" workers, or "street level" bureaucrats (Newton 2001; Lipsky 1980; Prottas 1978) in policy 
implementation. These implementers are the "real makers" of policy through relative autonomy at implementation point.

Students have been forced to cling to university course content and kept away from questioning its relevance, elasticity and durability in relation to the needs of community, industry and other stakeholders. It is in the disruptive questioning that student involvement procedures evoke innovations with potential for commercialisation, thereby revolutionising the education experience and salvaging some professions from extinction. Responding to these rigidities, the Zimbabwean government coined and introduced Doctrine education 5.0, investing in HEIs' quality assurance infrastructure. The doctrine, however, does not outline student involvement roles and activities hence the need to ascertain these to avoid "being blind" to students.

\section{OBJECTIVES OF THE STUDY}

1. To determine students' roles in HEIs quality assurance processes

2. To identify student involvement policy gaps in HEI governance

\section{THEORETICAL FRAMEWORK OF ANALYSIS: STUDENT INVOLVEMENT THEORY}

Astin's Theory of Student involvement posits that student involvement is the amount of physical and psychological energy a student devotes to the academic experience (Astin 1999). It has five postulates, first of which assumes involvement refers to the investment of physical and psychological energy in various objects. The second says involvement occurs along a continuum where different students exhibit varied degrees of involvement in different objects at different times. Thirdly, Astin quips that time spent alongside comprehension levels makes involvement quantitative and qualitative. The fourth postulate assumes that the amount of student learning and personal development is determined by the quality and quantity of involvement a student invests in a program.

Its fifth and last assumption entails that the effectiveness of any educational policy or practice is directly related to its capacity to increase student involvement. Involvement takes place in diverse platforms like student organisations, campus magazines or news, student representation councils (SRC), absorption in academic work, internships, participation in extracurricular activities like intercollegiate sports, and interaction with faculty and other institutional personnel (Luescher-Mamashela 2013; Astin 1999). In concurrence, Tinto (1993, 208) posits that a sense of "competent membership" results from student interaction with faculty and staff, among other factors. 
Building on Astin's five postulates, Luescher-Mamashela (2013) identifies four principles underscoring student involvement. These include the political realist, where students are involved for pacification. The consumerist principle that involves students as clients who should contribute to decisions affecting them. The communitarian principle seeks student involvement as communal members bound by shared HEI goals and surroundings. Lastly, the democratic and consequentialist case recognises students as autonomous individuals treating involvement as a platform for their personal growth and satisfaction (Luescher-Mamashela 2013). The notion of consequentialist entails consequences for involvement as well as noninvolvement. D'Arcy (2014) attests to the relationship between student involvement and desired QA outcomes like student learning, academic achievement, student development, success that comes with increased satisfaction with the college experience. Regardless of the reasons for involving students, Mulinge, Arasa and Wawire (2017) submit that such collaboration is essential for universities to attain their visions, missions and goals.

According to Astin (1999), student involvement theory provides a link between the variables of the most common theories of education which are the subject matter, resources, and individualization of approach theories and the learning outcomes desired by the student and the professor. These theories place a lot of emphasis on course content and lecture attendance; rely on the adequacy of resources like visible instructors, laboratories, libraries, audio-visual aid, astute students among other resources as guarantee for quality attainment and self-paced individualised learning respectively (Astin 1999). Student involvement on the other hand, subsumes the desirable characteristics of these theories by emphasising the depth of involvement and its significance in determining levels of student learning and personal development.

The theorists suggest the effectiveness of any educational policy or practice depends on its capacity to involve students, largely because the success of such policy is dependent on the satisfaction of students as the key stakeholder at the core of QA outcomes. Qualifying student involvement for the effectiveness of education policies and practice, Agius (2011) asserts the university "as a market" must be responsive to the needs of students "as the central client". Since HEIs exist for their satisfaction, the depth of student involvement is strongly attached to desirable QA outcomes, Peck et al. (2016) further note it also helps students develop their skills in synchrony with industry requirements in a fun way.

Delfino (2019) locates student engagement within three dimensions which are behavioural, emotional, and cognitive which he says resonate well with student academic performance. It is through these dimensions that students develop feelings and connect to peers, professors, and institutions in affiliate ways that are instrumental in enriching the learning 
experience and environment (Hanrahan 1998). This assertion also finds support in Astin's student involvement theory where he quips that it "enhances almost all aspects of the undergraduate students' cognitive and affective development," (Astin 1993: 398). Kuh and Schuh (1991) concur with the attitudinal outcomes of student involvement, analytical and problem-solving skills, values, academic development, knowledge acquisition, and self-esteem. All these are qualities that denote satisfaction and physical and psychological well-being (Hernandez, Hogan, Hathaway and Lovelle 1999).

In recognition of the students' enrolment characteristics, competences and college environmental factors on subsequent college outcomes, Astin (1991) proposed InputEnvironment-Output model as a framework of analysis. The model emphasises the need to understand the qualities and characteristics students bring upon admission to HEI environments classifying them as input variables. It recognises the impact of personal pre-college characteristics, classifying them as inputs. Terenzini et al. (1994); Levin and Levin (1991) and Pascarella (1985) argue that student background/pre-college pulls and pushes from social, academic, and organizational spheres work together to shape student learning, persistence and cognitive development. Environmental variables on the other hand represent the totality of experiences in the educational environment while outputs refer to skills, knowledge, beliefs, attitudes and behaviour that exists after college (Astin 1995). Closely intertwined, Long and Amey (1993) submit that the effects of pulls and pushes should be considered simultaneously. According to the model, the evaluation of an institution's effectiveness is determined by measuring students' inputs against their outputs.

Interrogating the purpose of HE, Lagemann and Lewis (2012) submit that it goes beyond securing employment for individual income to fulfil a vital public purpose like leadership and service. Murwira (2019) also adds that the universities' role is to produce knowledge that results in goods and services with commercial application or other significance like creating jobs and helping communities. Examples of what QA and student involvement confluences can achieve in most developed and some developing countries include socially and commercially significant projects. According to Maker Faire (2019), these include projects like The Baby Saver 2000, an invention by Arkansas' Beebe Junior High School students. The Baby Saver protects babies left in cars from dying in extreme heat. There is the Wildlife detector created by Arizona's Snowflake Junior High students, which is a cheaper technology that detects encroaching animals to avoid road accidents. The Nebraska's Gering High School's Agricultural surveillance drones. Closer home, students from Uganda's Makerere University in 2009 invented the Kiira electric vehicle with a capacity to drive at $100 \mathrm{~km} / \mathrm{hr}$ and cover $80 \mathrm{~km}$ before the next recharge. 


\section{QUALITY ASSURANCE (QA)}

According to Seyfried and Pohlenz (2018), the practice of QA varies according to an institution's management decisions which not only depend on quality managers (QM) but involves top level management representatives as well. Van Der Bank and Popoola (2014) submit that it has three main components which include quality, standards and relevance. They further denote that quality education in the teaching and learning environment is a key performance indicator of any education institution (Van Der Bank and Popoola 2014). However, there have been suggestions that quality is difficult to achieve in developing countries (Kanyongo 2005).

\section{Quality}

Quality is a lucent term that tends to relate to a "thing" and "time". Thus, in the wake of a continuously evolving technological environment, education systems' quality is perpetually called into question alongside existing curricula and resultant skills and degrees. While Green (1994) says quality is an elusive concept that cannot be easily defined, Seyfried and Pohlenz (2018) argue that it does not mean it is beyond measuring. This study therefore proffers various definitions which attempt to cover every facet of quality in education in an evolving society. The simple Oxford Dictionary definition says it is "the standard of something as measured against other things of a similar kind; general excellence or archaic high social standing". ESIB (2019) and Van Der Bank and Popoola's (2014) definitions refer to continuity, agreed standards and structures that ensure or direct attention to high-quality content and results.

Zhao and Gallant (2012) however suggest that evaluation results are not a reliable and valid reflection of teaching quality. Further to this, Reeves and Bednar (1994) assert that quality should relate to "value, conformance to specific requirements and expectations, fitness for use and loss avoidance". In a society that keeps unleashing new inventions, quality should be that which is not necessarily the same but an improvement of the former and fitting well into its purpose. It should also fit into the contemporary unfolding society and be flexible and elastic enough to factor in constant changes and still manage to retain that elasticity and thus infinity. Where fitting into purpose and contemporary society are concerned, relevance comes in.

\section{Relevance}

For the discussion of relevance to make sense, it ought to be done within the context of a social setting. In line with Benito-Osorio et al.'s (2013) argument, university qualifications must be able to rise to the challenge of modern times, providing professional training that combines 
high level theoretical and practical knowledge that constantly adapts to society's present and future needs. The Oxford online and Merriam-Webster dictionaries concur in defining it as "the state of being closely connected or appropriate" and "a practical and especially socially applicable matter," respectively. Social applicability in this case refers to the contemporary unfolding technological revolutions. As has been observed over the years, technological change has been constant, moving sharply from the first to the third industrial revolution (IR).

Tracking technological change to respond to stakeholders' needs Schwab (2016) tracks the first IR as having been marked by use of water and steam power to mechanize production while the second IR used electric power for mass production. The third deployed electronics and information technology to automate production where the currently unfolding fourth IR is building on the previous digital revolution. It is integrated and comprehensive, involving all stakeholders of the global polity, from the public and private sectors to academia and civil society. Relevant education quality should be able produce graduates that relate to the unfolding changes which are also modifying business orientation (Benito-Osorio et al. 2013). According to Van Der Bank and Popoola (2014), QA methods with principles relevant to the African context would be more ideal. It was in line with this thinking that Zimbabwe's ministry of Higher and Tertiary Education, Science and Technology Development moved away introduced Doctrine education 5.0.

\section{ZIMBABWE'S DOCTRINE EDUCATION 5.0}

Doctrine 5.0 is a new model of education in Zimbabwe's higher institutions. Unlike model 3.0 which focused on (1) teaching, (2) researching and (3) community servicing, Doctrine education 5.0 adds two more pillars to the education system. These are innovation and industrialisation targeted at promoting the production of goods and services (GZU 2019; Jonathan 2019). According to Jonathan (2019), the model is an outcome focused education for problem-solving and value-creation set to make Zimbabwe competitive, modern and industrialized. In other words, it is a student involvement model that seeks to create solutions for the country through supporting university industrial innovation initiatives that impact on the national economy. Jonathan (2019) adds that Doctrine education 5.0 as spelt out by the minister should adequately prepare Zimbabwe for the demands of the currently unfolding fourth industrial revolution. In support of this new education concept, Murwira (2019) asserts that the country's education needed systems of capturing brains and using talent usefully to market Zimbabwe as the go-to place of education. He further notes that the ministry of education has built innovation hubs in all universities as platforms of the confluence of government, students and organisations, demonstrating that student involvement is key in the quest for QA. 


\section{STANDARDS}

The glossary of Education Reform (2014) submits that learning standards are concise, written descriptions of what students are expected to know and be able to do at a specific stage of their education. They serve as the basis of the national educational reform that guides educators and policy makers in clearly defining desired outcomes and how they relate to success (National Research Council 2001). Fourteen years after Kanyongo (2005) ascribed the dearth of standards in the Zimbabwean education to lack of funding, the ministry of HE has set to sponsor researchers' projects towards harvesting intellectual products.

\section{METHODOLOGY}

According to Zikmund et al. (2003), research methodology is a framework that outlines methods and procedures to be followed when collecting and analysing the required information from respondents. The study deployed the pragmatic research paradigm. According to Goldkuhl (2012), pragmatism is concerned with action and change and the interplay between knowledge and action. Given the case study at hand, it becomes appropriate as a basis for intervening into the ways in which HEIs involve students. Goles and Hirschheim (2000) suggest that pragmatism is pluralist in nature, using method combinations that work in relation to the research purpose and current empirical situation. Goldkuhl (2012) however notes that while pragmatism means pluralism, not all pluralism is pragmatic.

Questionnaires were administered to 45 respondents, 15 of which were quality assurance managers and 30 students, nine of which were either part of or former members of the Student representative Council (SRC), five members of the alumni and the rest reigning students. Only 40 responded. "Exploring gaps and implications for higher-education-institutions" is a sensitive topic which could potentially jeopardise an institution's reputation to the point of decampaigning it as a go-to place of education. The chosen approach therefore concealed the names of respondents and their institutions as a way of avoiding a possible linking of the two. It used a deductive approach and strictly adhered to ethical concerns of informed consent, confidentiality and privacy. Data was collected from Bulawayo HEIs through self-administered and postal questionnaires sent to respondents via email. Questionnaires used both open and close ended questions depending on the type of required data.

\section{FINDINGS/DISCUSSIONS}

Student involvement is a relatively new concept that only came to Zimbabwe with the introduction of Doctrine education 5.0. While it was being practised over the years, there were 
no specific structures to accommodate it as a practise. One of the students noted that students bodies' grievances are usually not taken seriously, and their protests dismissed as hooliganism despite representing students' views. They lamented that their involvement was limited to platforms like the council and students' representative councils, and its extent not empowered to make substantial decisions. Below are emerging major findings and the related graphical illustrations.

\section{Student involvement is impossible without compromise}

Lectures had mixed views on the implications of student involvement in their institutions' governance issues. On the other hand, students expressed concern that the involvement of students working as teaching assistants was giving them access to the institutions' systems and restricted information, including that of other students. Such a scenario, they feared, could compromise other students if the confidentiality policy was not clear enough. Figure 1 demonstrates that 25 out of 40 students resonate with the assertion that involvement is impossible without compromise.

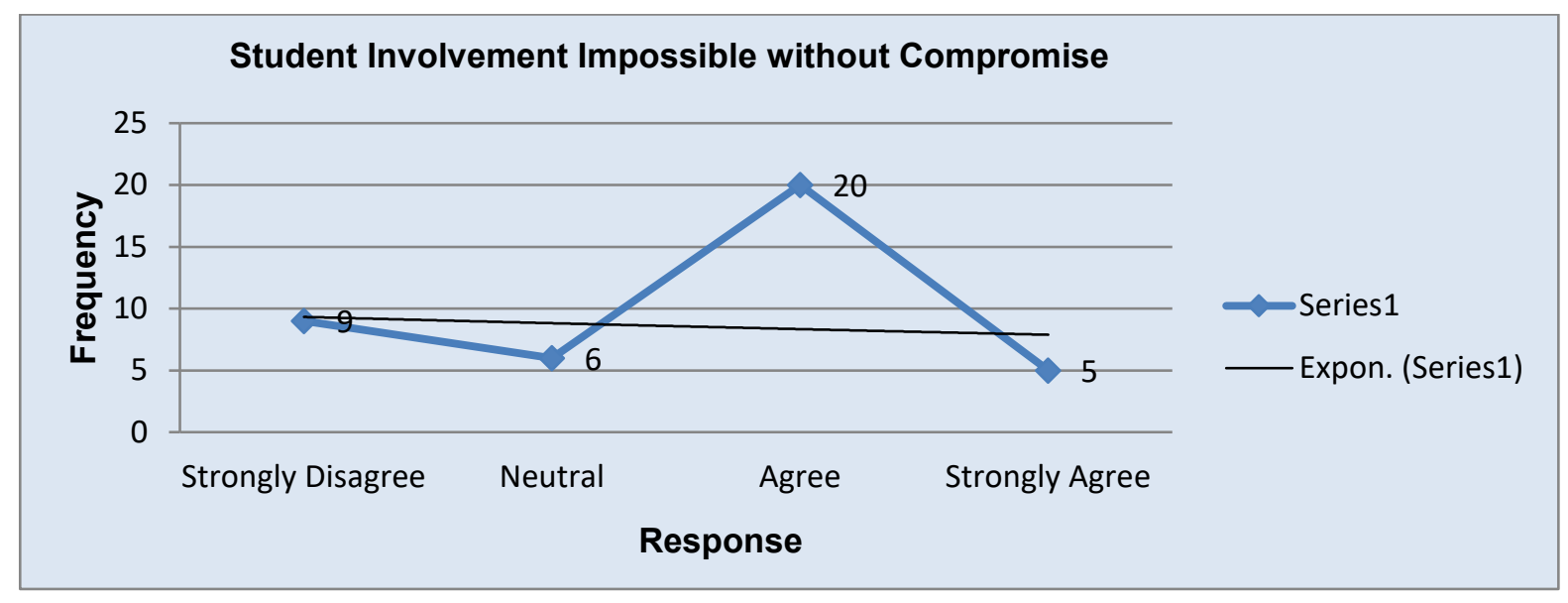

Figure 1: Student Involvement and Compromise (Source: Primary Data)

\section{Lecturers' lack skill or experience}

As demonstrated in the Figure 2, 22 out of 40 students and lecturers agreed that some lecturers lack industrial experience. As a resultant, the majority felt it compromises the quality of delivering or explaining concepts while others had varying opinions. Observing that quality entails education in line with the demands of both the local and international market and standards of expertise expected from graduates, students found some lecturers' lack of skill or experience disturbing. This is because it directly affects their skills set and marketability particularly in the international spectrum. 


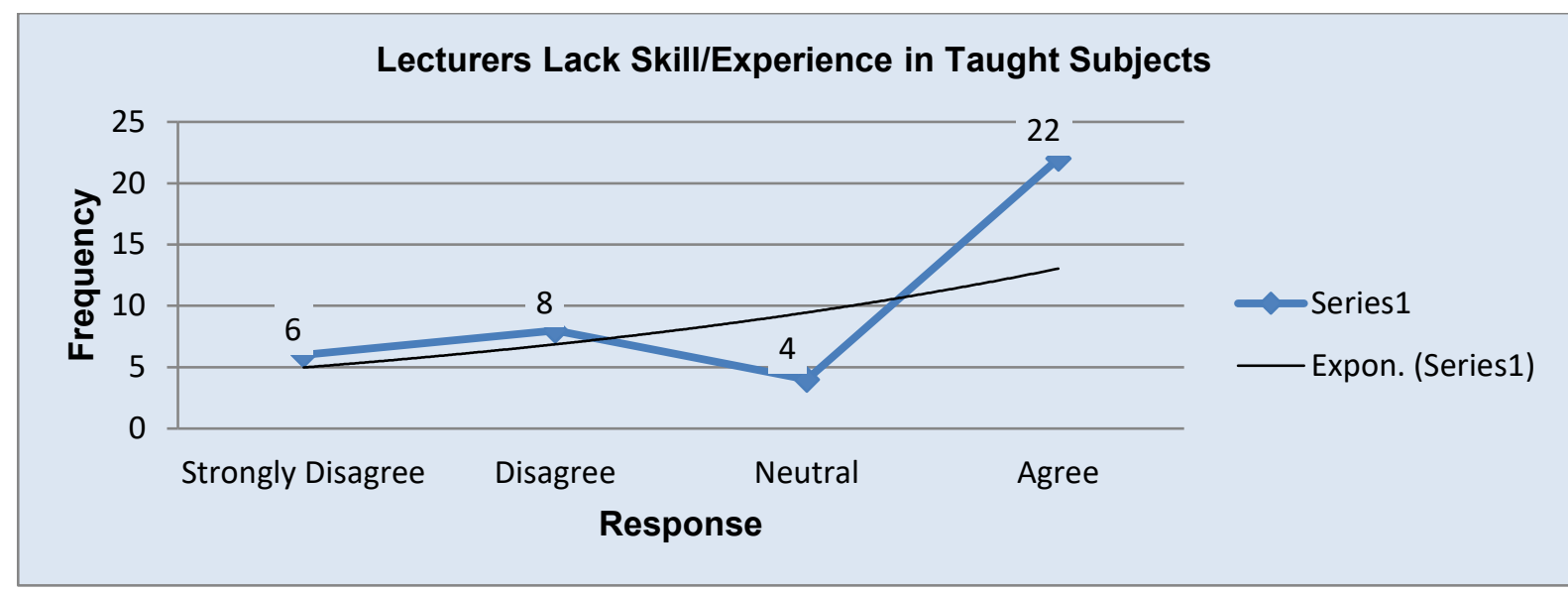

Figure 2: Student Involvement and Compromise (Source: Primary Data)

\section{The Zimbabwean government should undertake to modernise both industry and their institutions}

Despite the nobility of the ministry's idea of getting university prototypes, the general feeling was Zimbabwe's education would take ages to catch up with the rest of the world as a result of archaic or inadequate technologies. Both students and lecturers indicated that student involvement could only compliment government and not their own partial and usually illfunded efforts to achieve QA. Lecturers and students alone would not be able to meet the diverse needs of industry if the government does not commit to modernising the industry itself. The limitations on infrastructure and learning technologies has notable repercussions on student support and thus retention.

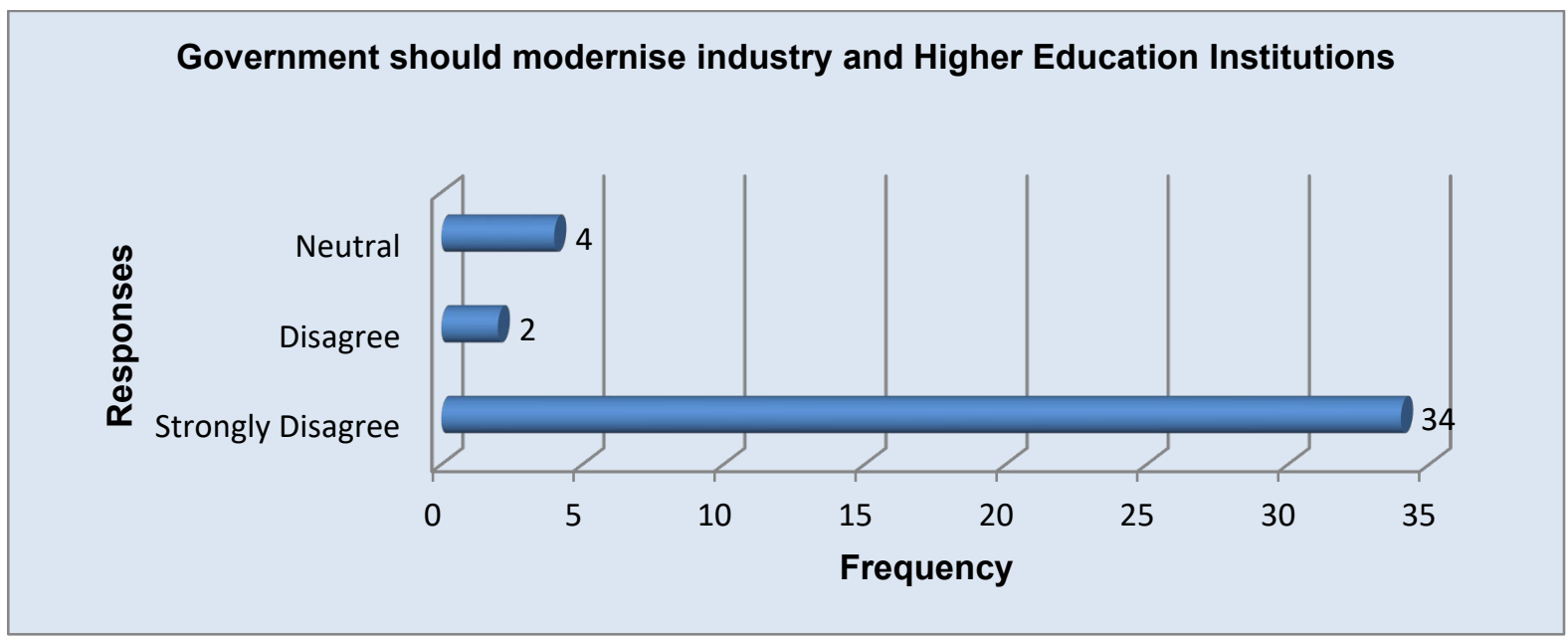

Figure 3: Student Involvement and Compromise (Source: Primary Data)

\section{There is no harmony between industry, education sector and government}

Only 14 out of 40 respondents disagreed that there was disarray between industry, the education 
sector and the government. While HEIs produce ideas intended to tackle QA issues, they do not have the capacity to operationalise those ideas. On the other hand, what contemporary industry is practising is totally divorced from the government's visions for the country.

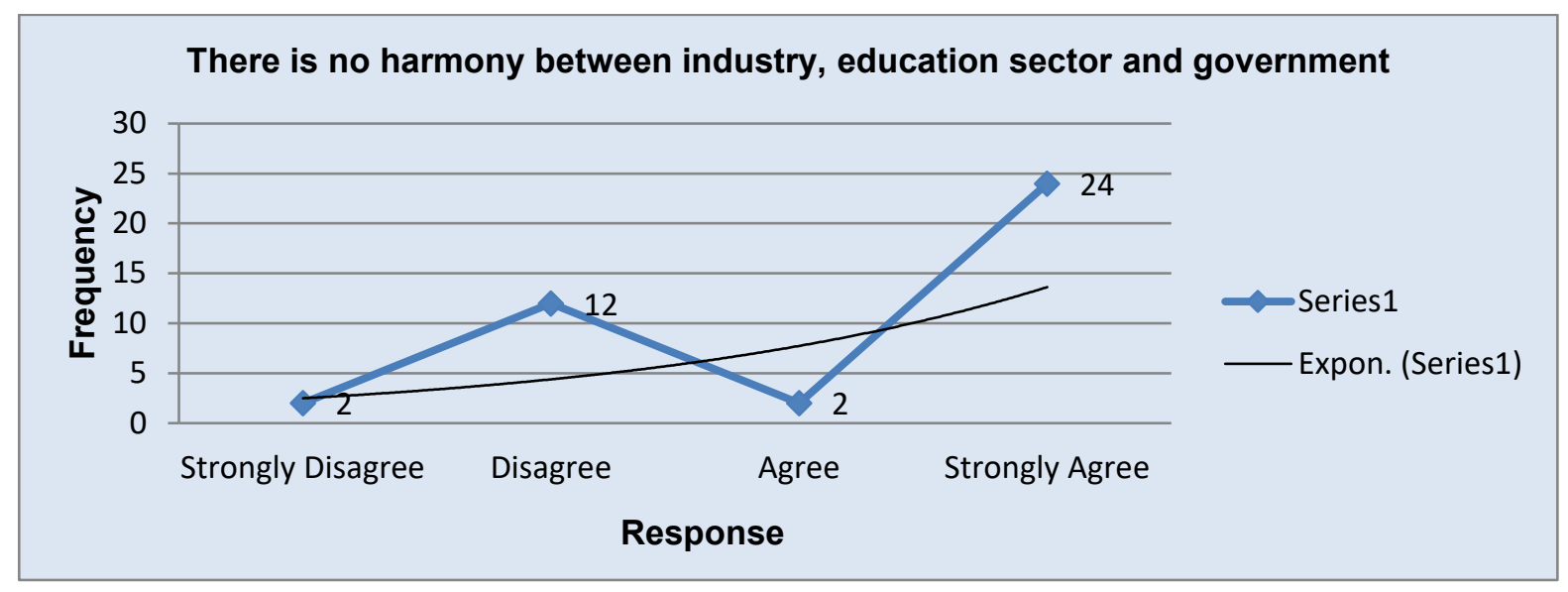

Figure 4: Student Involvement and Compromise (Source: Primary Data)

\section{CONCLUSIONS}

This section presents the conclusions based on the two stated objectives.

\section{Students' roles in HEls quality assurance processes}

From the findings, it emerges that students' participation through the SRC, Council and as teaching assistants remains limited and their roles vague if not totally blurred even after the introduction of Doctrine education 5.0. While the model does allude to involvement, it has no clear policy on student involvement procedures or the roles to be assumed upon involvement. Decision making still lies with HE authorities, cascaded to the students in a top down or tokenistic manner that renders the current involvement meaningless. The ordinary student who only participate at the end of the chain through a rigid adherence to set standards of operandi like writing course work or doing research are in a deeper quandary as their inputs may never be heard.

\section{Student involvement policy gaps in HEI governance}

Gaps still exist in research that should facilitate the confluence of market, student and institutions' demands to design learning material and modes of delivery. For example, where institutions encounter financial constraints to deliver field instead of class lectures, students' input are bypassed, and no consultations made in case they could fund their education. As a result, they are short-changed, sailing to the graduation stage with no proper exposition to the operational environment. Consequentially, institutions further burden the market with 
incompetent graduates who can barely deliver without further on the job training. Further to this, organisations end up bypassing graduates in preference of the experienced worker to save their resources.

\section{RECOMMENDATIONS}

1. The country should design a more student-centred learning system which will adopt new approaches of learning that are not only relevant to unfolding societal needs, but also appeal to all students in their diversity. To make that involvement meaningful, students could be involved from the planning stages of everything that affects them, from fees to the formulation of course content, calibre of lecturers for the courses and development projects in their universities.

2. The government, in collaboration with HEIs should identify the best brains, fund their attainment of updated skills set from modernised countries abroad and give them targets to impart the same to local students and concurrently, modernise industries to ensure that newly attained skills find a platform for applicability.

3. Lecturing in engineering department should be done by individuals who are conversant with industrial requirements and operational systems to help students appreciate the technologies in use.

4. Environment analysis should be done by both the Institution and the students while students are on attachment. The resultant feedback should be analysed by both parties and outcomes incorporated into the learning material. This will avoid blindness to market expectations and changing trends. It will also ensure that course content is continually in line with contemporary trends.

\section{REFERENCES}

Agius, Karl. 2011. The status of student participation in Europe. The European Students' Union Aghveran, Armenia.

Aikman, David. 2017. The fourth Industrial revolution and society 5.0. World Economic Forum (WEF) 3. Davos. https://www.youtube.com/watch?v=faC-9rDZWUQ

Astin, Alexander, W. 1991. Assessment for excellence. New York: ACE Macmillan.

Astin, Alexander. W. 1993. What matters in college: Four critical years revisited. The Journal Higher Education 22(8): 74-75.

Astin, Alexander, W. 1995. The cause of citizenship. Chronicle of Higher Education 6 October.

Astin, Alexander, W. 1999. Student involvement: A developmental theory for higher education. Journal of College Student Development 40(5): 518-529.

Benito-Osorio, D., Guerras-Martín L. Ángel and Zuñiga-Vicente J. Ángel. 2013. Four decades of research on product diversification: A literature review. Management Decision 50(2): 325344. https://doi.org/10.1108/00251741211203597. Emerald Group Publishing Limited. 
D'Arcy, Kelly. 2014. Structural dimensions of student involvement and their relationship to student development. PhD dissertation, Oklahoma State University.

Delfino, Armando P. 2019. Student engagement and academic performance of students of Partido State University. Faculty of Education, Partido State University, Philippines.

Education Reform. 2014. Education reform 2014. https://repurposingeducationreform.blogspot. $\operatorname{com} / 2014 /$

ESIB. 2019. Science meets economy. Graz, Australia. https://esib2019.b2match.io/

Garwe, E. C. 2014. The effect of institutional leadership on quality of higher education provision. Research in Higher Education Journal 22.

Goldkuhl, G. 2012. Pragmatism vs interpretivism in qualitative information systems research. European Journal of Information Systems 21(2): 135-146.

Goles, Tim and Rudy Hirschheim. 1999. The paradigm is dead, the paradigm is dead ... Long live the paradigm: The legacy of Burrell and Morgan. Omega 28: 249-268.

Great Zimbabwe University (GZU). 2019. Education 5.0 unpacked. News Magazine. https://services. gzu.ac.zw/news/

Green, D. 1990. What is quality in higher education? Buckingham, UK: Society for Research into Higher Education and Open University Press.

Hanrahan, Mary. 1998. The effect of learning environment factors on students' motivation and learning. International Journal of Science Education 20(6): 737-753. Taylor \& Francis.

Hernandez, Karen, Stacey Hogan, Cynthia Hathaway and Cheryl D. Lovell. 1999. Analysis of the literature on the impact of student involvement on student development and learning: More questions than answers? NASPA Journal 36(3): 184-197.

Jonathan, Enock. 2019. Education 5.0 - towards problem-solving and value creation. Bulawayo 24 News. https://bulawayo24.com/index-id-opinion-sc-columnist-byo-157170.html

Kanyongo, Gibbs Y. 2005. Zimbabwe's public education system reforms: Successes and challenges. International Education Journal 6(1): 65-74.

Kuh, George D. and John H. Schuh. 1991. The role and contribution of student affairs in involving colleges. National Association of Student Personnel Administrators, Inc., 1875 Connecticut Ave., NW, Suite 418, Washington, DC 20009-5728.

Lagemann, Ellen C. and Harry Lewis. 2012. What is college for? The public purpose of higher education. Teachers College Press. 1234 Amsterdam Avenue, New York.

Lipsky, Michael. 1980. Streel level bureaucracy: Dilemmas of the individual in public services. Russell Sage Foundation, New York.

Long, Patricia N. and Marilyn J. Amey. 1993. A study of underprepared students at one community college: Assessing the impact of student and institutional input, environmental, and output variables on student success. Paper presented at the Annual Meeting of the Association for the Study of Higher Education. 4 November. https://files.eric.ed.gov/fulltext/ED365177.pdf

Luescher-Mamashela, Thierry M. 2013. Student representation in university decision making: Good reasons, a new lens? Studies in Higher Education 38(10): 1442-1456.

Maker Faire. 2019. Maker Faire. https://makerfaire.com/

Mulinge, Munyae M., Josephine N. Arasa and V. Wawire. 2017. The status of student involvement in university governance in Kenya: The case of public and private universities. CODESRIA.

Murwira, Amos. 2019. Education 5.0 - towards problem-solving and value creation. http://www. mhtestd. gov.zw/?p=3501

National Research Council. 2001. Classroom assessment and the National Science Education Standards. Division of Behavioral and Social Sciences and Education. National Academies Press.

Newton, Kenneth. 2001. Trust, social capital, civil society and democracy. International Political Science Review 22(2). Sage journals. 
Pascarella, Enerst T. 1985. College environmental influences on students' educational aspirations. Sociology. The Journal of Higher Education 55(6): 751-771. Taylor \& Francis. https://doi.org/10.1080/00221546.1984.11778692

Peck, A., C. Cramp, L. Croft, T. Cummings, K. Fehring, D. Hall and J. Lawhead. 2015. Considering the impact of participation and employment of students in campus activities and collegiate recreation on the development of the skills employers desire most. http://nirsa.net/nirsa/wpcontent/uploads/ NACA_NIRSA_White_Paper.pdf

Prottas, Jeffrey, M. 1978. The power of the street - Level bureaucrat in public service bureaucracies. Urban Affairs Quarterly 13: 289.

Reeves, C. A. and D. A. Bednar. 1994. Defining quality: Alternatives and implications. The Academy of Management Review 19(3): 419-445.

Schwab, Klaus. 2016. The fourth industrial revolution: What it means, how to respond. World Economic Forum 14(1). Crown Business.

Seyfried, Markus and Philipp Pohlenz. 2018. Assessing quality assurance in higher education: Quality managers' perceptions of effectiveness. European Journal of Higher Education 8(3): 258-271.

Tapera, Julius. 2016. Promoting quality assurance in Zimbabwean higher education institutions: Concepts, systems and processes. https://www.researchgate.net/publication/311186790

Terenzini, Patrick T., Laura I. Rendon, Lee M. Upcraft, Susan B. Millar, Kevin W. Allison, Patricia L. Gregg and Romero Jalomo. 1984. The transition to college: Diverse students, diverse stories. Research in Higher Education 35: 57-73.

Tinto, V. 1993. Leaving college: Rethinking the causes and cures of student attrition. $2^{\text {nd }}$ Edition. Chicago: University of Chicago Press.

Van Der Bank, C. M. and B. A. Popoola. 2014. A theoretical framework of total quality assurance in a university of technology. Academic Journal of Interdisciplinary Studies 3(4): 401.

Zhao, Jing and Dorinda J. Gallant. 2012. Assessment \& Evaluation in Higher Education 37(2): $227-$ 235.

Zikmund, William G., Barry J. Babin, Jon C. Carr and Mitch Griffin. 2003. Business research methods. $7^{\text {th }}$ Edition. Thomson/South-Western. 